\title{
TÜRK MEDENİ KANUNUNDA EVLENMEDE MUTLAK BUTLAN.
}

Prof Dr. Şakir BERKI

\author{
§. 1 - MUTLAK VE NISBÎ MÂNILER ARASINDAKİ \\ FARK :
}

Medeni kanun, evlenme mânilerini üçe ayırmıștır. Bunlardan biri evlenmenin mutlak butlanını mucip manîlerdir. Diğer ikisi nisbî butlan ile butlanı mucip olmayan mânilerden ibarettir. Evlenme, nisbî butlan sebeplerinden biri mevcut iken akdedilmiș ise, evliliğin butlanına karar almak, münhasıran nisbî butlan sebebine maruz bulunanın talebiyle mümkündür. Kanunî mümessilin dahi bu hususta temsil selâhiyeti yoktur. Esasen bu halde evlenme, kișiyi reşit kılacağından evlenme akdi ile birlikte kanunî temsil de kendiliğinden kalkar. Mamafih evlendikten sonra hacir sebebiyle mahcura vasî tâyin edilse ve kendisine vasî tâyin edilmiș olan tarafın, evliliğini hata veya sair nisbî butlan sebeplerinden $\mathrm{bi}^{-}$ ri ile ref edebilmek için iktiza eden zaman aşımı da henüz dolmamış bulunsa, vasî geri kalan müddet içinde mahcurun rızası olmaksızın (1) nisbî butlan davâsı açamaz. Hacir, akıl hastalığından başka sebeplerle vâki olmuș ise, vasî, mahcurun isteği ile onun namına nisbî butlan dâvasını açabilir. Halbuki mutlak butlan ile malûl olan evlenmelerde taraflardan $h^{e} r$ ikisi de gayrı mümeyyiz olsa, gerek savcı gerek sair alâkalılar butlan davasını ikame edebilirler. Çünki bu davâ savcı tarafından açıldığı takdirde ammeyi temsilen ika-

(1) Vasî tâyini akıl hastalığı sebebiyle vaki olduğu takdirde nisbî butlan dâvası hiç açılamaz. Zira, bu mahcurda temyiz kudreti, binnetice, vasiye ruza beyanı mevzubahis olmaz. 
me edilir, sair alâkalılar tarafından açıldığı zaman kendi menfaatlerine taallûk eder.

Nisbî butlanla mutlak butlan davası arasındaki ikinci fark, mutlak butlan sebepleri dolayısıyle her alâkalının ve âmme namına savcının davâ açma yetkisi vardır. Halbuki, nisbî butlan sebepleri ile malûl evlenme, savcı ve alâkalılar tarafından hiç bir zaman nisbi butlan davası ile yok edilemez. Ancak alâkalılar, yani nisbi butlan davasını ikame edecek olan tarafın mirasçıları, (2) dâva açıldıktan sonra davâcının ölümü halinde davâyı devam ettirebilirler: Kayd edelimki, davanın devam ettirilmesi, aile hukuku bakımından mana ifade eder. Yoksa hayatda kalan eșin, yani nisbi butlan sebebi ile malûl olan evlenmede taraf olan șahsın hayatta kalan eș sıfatiyle miras hakkı ihlâl edilemez. Çünki gerek mutlak, gerek nisbi butlan kararına kadar bâtıl evlenme, sahih, yani mutlak ve nisbi butlan sebepleri ile muallel olmayan evlenmenin bütün hüküm ve neticelerini doğurur. Șu halde, nisbî butlan davâsı açıldıktan sonra, fakat butlan kararı verilmeden evvel davacı ölse, hayatta kalan eş, onun sahih eşi imiș gibi mirascı olur. Binnetice, Devlet nisbî butlan davâsını devam ettirmekte menfaat sahibi addedilemez. Şu halde, Hazinenin bu davayı devam ettirmesine lüzum yoktur; hatta bu hususda selahiyeti'de olamaz.

120 inci maddedeki fesih davası, 127 inci maddedeki hükümle alâkalı değildir. Bu sonuncu madde yalnız nisbî butlan sebebi ile feshe münhasirdir. Esasen 120 nci maddenin derpiș ettiği fesih davasında, ikame edilen davânın mirascıya intikali mantıkla da kabili telif olamazdı. Zira $120 \mathrm{nci}$ madde mucibince vasinin de fesih davası açmaya hakkı vardır. vasî, fesih davâsını açtıkdan sonra ölse, mirascılarının bu davâyı tâkip etmeleri düșiinülemez. 120 inci maddededi $\mathrm{fe}^{-}$ sih hakkının mutlak olmayışı, bu maddenin 2 inci fıkrasındaki hükmün mahiyeti ile de teyit olunur. Halbuki nisbi butlan davası hakkı 120 inci maddenin 2 inci fıkrasındaki hal-

(2) Mirascılardan maksat kanunî ve mansup mirascılardır. Muayyen mal vasiyeti ile terekeden klymet alacak olanlar davayı devam ettiremezler. Zira bunlar mirascı (vâris) değildirler. 
lerde sâkıt olmaz. Hülâsa 127 inci maddenin mirascılara davâyı tâkip için verdiği hak, ancak nisbi butlan davası içindir. Nisbi butlan davâsını açmaya haklı olan, nisbi butlan sebebine maruz olan taraf olduğundan, bunun davâ ikamesinden sonra vefatı halinde, davânın mirascıları tarafından tâkip edilmesi'de mantıkidir. Ancak tekrar hatırlatalım ki, davânın takibi hayatta kalan eşin miras hakkını ref edemez. Zira ölümle miras açılır ve henüz nisbi butlan kararı verilmemiş olduğundan hayatta kalan eșin miras hakkı, hakkı müktesep olur.

3) Nisbi butlan ile mutlak butlan arasındaki farklardan biri de, nisbi butlan davâsında zaman aşımı kabul edildiği halde (3) mutlak butlan davasında zaman aşımının mevzuubahis olamıyacağıdır. Filhakika, mutlak butlan sebepleri, mahiyetleri itibariyle amme intizamına ve hatta umumî ahlâka, (4) daimî surette aykırı olduklarından, mutlak butlan dâvasında müruruzaman kabul etmek, âmme intizamına ve ahlâka aykırılığı tasvip eylemek olurdu. Meselâ yekdiğeri ile evlenmiş olan baba ile kızının veya ana ile oğlunun evlililiğine muayyen bir müddet sonra taarruz edememek doğru olamazdı. Çünki bu evlenmeler ahlâk ve adabı umumiyeye muhaliftir, devam ettikleri müddetçe amme vicdanını ve müşterek ahlâkı rencide ve rahatsız eder. Diğer mutlak butlan sebepleri de aynı tesiri icrà edeceğinden, mutlak butlan davâsında müruruzaman (zaman aşımı) kabul edilemez. Poligami ve Poliadride de hüküm aynıdır (5).

(3) MK. Md : 119 a göre nisbî butlan davâlarında, biri hususi đigeri umumi olmak üzere iki mururuzaman vardır. Hususi 6 ay umumi 5 senedir; Bu husus da fazla bilgi için: Ş. Berki Medenî Hukuk, Ankara, 1961, sa : (132-133).

(4) Amme intizami ile umumî ahlałk ayrı şeydir. Bir hareket amme intizamına aykırı olduğu halde, amme ahlâkına aykırı olmaz: daimi akıl hastalığının evlenme manii oluşu amme intizamına aykundır; fakat ana, baba, Kaim vâlide ile evlenmek umumî ahlakka aykıridır.

(5) Poligami, esasen evli bir erkeğin birinci evliliği devam ederken ikinci bir evlenme akd etmesidir. Poliandri ise, evli bir kad1nın ikinci evlenme akd etmesidir ki, bu Hukuk tarihinde hiç tecviz edilmemiş, Poligami ise halen bu gün bazı memleketlerde meșru olarak devam eylemektedir. Hatta Roma huku- 
§. II - MUTLAK BUTLAN SEBEPLERİ : (ML : 112) :

112 inci madde mutlak butlan davâsına mahal veren sebepleri kayd ediyor :

I - Evlilik. Md : 112/1.

Mezkûr fıkraya göre, karı kocadan biri evlenme merasiminin icrası sırasinda evli ise, ikinci evlilik mutlak butlanla bâtıldır.

$\mathrm{Bu}$ hïkmïn izahı lâzındır: İlk evlilik mutlak butlanla bâtıl olsa bile, ikinci evlilik isterse mutlak veya nisbî butlan sebeplerinden hiç biri ile malûl bulunmasın mutlak butlanla bâtıl olur. Bir şahıs kaim validesi ile her nasılsa evlendirme memuru huzurunda ve kanunî merasimine göre evlenmiștir. kaim valide ile vâki evlenme mutlak butlanla malûl olduğundan (6), butlan kararma kadar sahih evlenme gibidir (7). Şimdi aynı șahıs, her nasılsa akıl hastalığına müptelâ olmayan ve hısım da bulunmadığı bir kadınla evlense, bu evlenme bâtıl olur. Keenlemyekûn olmaz. 124 ncï maddenin 2 inci fıkrası hükmü bu hususda sarihdir. Binnetice, bir erkek her nasılsa ikinci ve üçüncü kadınla evlense veya evli bir kadin her nasilsa ikinci ve daha ziyade erkekle evlenme akd etse, bunlar aynı evde fazla evlilik camiası içinde oturabilecekler, ve bu çok evliliğe ve birlikde ikamete polis dahi müdahale edemiyecektir. Çünki Medenî kanunun 124 üncü maddesi mutlak butlanla bâtıl evlenmelere, butlan kararina kadar aynen sahih evlenmenin bütün hüküm ve neticelerini taniyabilmiştir. Bizce İsviçre ve Türk kanun koyucularının bu hareket tarzı çok hatalıdır. Zira, her ikisi de hem poligami ve poliandriyi titizlikle men ediyor, hem de, 124 üncü mad-

kunda da muayyen bir devre kadar Concubinatus fiili poligamik evlenme hayatina vesile olmuştur.

(6) Md. K. Md : 92/2;112/3. Evlilik zeval bulsa bile eski eşler yekdiğerinin usul ve füruu ile evlenemezler. lâkin evliliğin zevalinden sonra edindikleri fürularla evlenme manii yoktur Fazla bilgi için \&2, No. III, 4. e bakınız.

(7) M. K. Md : 124/: «evlenme mutlak butlan ile malul olsa bile hakimin kararna kadar (butlan karar1) sahih bir evlenmenin hükümlerini haizdir». 
denin izah edilmiş olan garip hükmünü tasvip eyliyorlar ki, bu, kanun yapma san'atı bakımından tenkide șâyandır. Her iki kanun vâzının mutlak butlan sebepleri ile malûl olan evlenmeleri keenlemyekûn addetmesi ve ancak bu evlenmelerden doğan çocukların nesebinin sahih sayılacağını beyanla yetinmesi iktiza ederdi. Çocuğun nesebinin sahihliğini temin için ikinci ve üçüncï evlenmeleri aynen sahih evlenme gibi addederek poligami ve Poliandriye mahal veren hükümlerin kabulü câiz olamaz. Medenî Kanunumuzda değişiklik yapllmak ihtiyacı hissedildiği zaman bu cihetin bilhassa nazardan kaçırılmaması șâyanı temennidir.

Mutlak evlenme manii sebeplerinden Poligami ve poliandri bahsinde, 114 üncü maddenin 3 üncü bendi hükmünde de durmak lâzımdır : "Evli iken yine evlenen bir kimsenin bu evlenmesine butlan hükmü verilmeden evvel, vefat ve sair sebeplerle evvelki evlenme zâil olmuş olur ve yeni evlenmede de diğer taraf hüsnüniyet sahibi bulunur ise, butlana hükmolunamaz».

Bu hükmün șu suretle izahı gerekir :

Evli bir erkek veya esasen evli bir kadın bu evliliğin farkında olmayan diğer bir kadın veya erkekle evlense, ve birinci evlenme ölüm, boșanma, nisbî veya mutlak butlan yahut kanunî mümessillerin fesih davası ile zâil olsa, artık ikinci evlilik mutlak butlanla ref edilemez. Medenî kanunun bu hükmü, islâm hukukunun (Fıkıh) Borçlar hukuku hükmünde olan Mecelledeki "Mâni zail oldukda, memnû avdet eder» kaidesinin tatbikinden bașka bir șey değildir. Kuvvetli bir mantığa dayanan bu kaidenin, Medenî kanunda mutlak butlan bahsinde tatbik sahası bulmuş olması makuldür. Zira aksini kabul etmek, hiç sebep yok iken teessüs etmiş olan bir aileyi, bir ocağı beyhude yere söndürmek olurdu ki, maslahat ve amme intizamı muilâhazaları buna cevaz vermez. Son olarak kayd edelimki, 112/1 deki poligami ve poliandri memnuiyeti dolayısıyle, ikinci evliliğin mutlak butlanla malûliyeti, esasen mevcut evlenmenin Medenî kanunun istediği şekilde akd edilmiş olan evlenmelerden olması halinde kabili tatbiktir. Binnetice, bir şahıs diğeri ile resmî nikâh yapmaksızın, Kilisede veya islâm hukukuna uyarak yalnız iki şâhit 
huzurunda evlense ve karı koca gibi yaşasalar, sonra aynı şahıs bir başkası ile Medenî kanun mucibince evlense, bu evlilik çok evlilik sebebiyle butlanla malûl olmaz. Zira, Kilisede Papaz huzurunda yapılan evlenme ve islâm hukukunda iki șâhit huzurunda akd edilen nikâh, medenî kanuna göre bâtıl değil, keenlemyekûn gayrı mevcuttur (8).

Şu ciheti de kayd edelim ki, ilk evlilik Medenî Kanunun emrettiği merasime uyularak yapılmamıs ise, yine keenlemyekûndur. Meselâ iki şahıs evlendirme memuru huzurunda, fakat şâhitsiz veya bir şâhidin huzuru ile evlenseler, bu evlenme, evlendirme memuru huzurunda ve onun marifetiyle akd edilmiş olmasına rağmen mevcut bir evlenme değildir. Zira, merasimde iki șâhit bulunması, resmì bir akit olan evlenme akdinin rüknünü teșkil edecek kadar kat'i bir şarttır. Netice itibariyle, yukarda zikredilen evlenme akdinden sonra, evlenenlerden biri usulüne uygun şekilde başka biri ile eviense, bu evlenme poligami veya poliandri yasağı dolayısıyle mutlak butlanla malûl saylamaz.

II. Akıl hastalı̆̆ı ve dâimi surette temyiz kudretinden mahrumiyet Md: 112/2.

Akıl hastalığının veya daimi surette temyiz kudretinden mahrumiyetin evlenme akdi sırasında mevcut olması lâzımdir.

Akıl hastalığı dâima mutlak butlan sebebidir. Temyiz kudretinden geçici surette mahrumiyet, nisbî butlan davasına meydan verir (9); Mulak butlan davasina vesile olmaz.

(8) Şurada işaret etmek lâzımdır : İkinci evlilik hakkında butlan kararı alınamaması için, diğer mutlak butlan sebepleri ile malâl bulunmaması lâzımdır : bir şahıs evlidir, bu evlilik devam ederken dâimî akıl hastalığına müptelâ diğer bir şahısla, veya, usul yahut füruu ile veya sâbık eşinin ana veya babası (kaim valide, kaim peder) ile evlenme akdi yapmak imkânı buluyor. Kendisi ile ikinci evlenme akdedilen bu şahıslar, hüsnüniyet sahibi olsalar ve çok evlilik dolayısiyle butlana karar alınmadan evvel ilk evlilik zeval bulsa bile ikinci evlilik hakkında butlan kararı yine alınır.

(9) M. K. Md : 116. 
Daimi akıl hastalığının evlenme akdinden sonra zuhur etmiş olması, boşanma sebebi olup mutlak butlan davâsiyle alâkalı değildir (10).

Her akıl hastalığı evlenme manii sayllamaz. Evlenmeye mani olabilen akıl hastalığı temyiz kudretini daimi surette selb edici mahiyette olmak lâzımdır. Devre devre tezahür eden akıl hastalıkları ne mutlak, ne nisbî butlan sebebidir. Normal devrede evlenme akd edilmiş ise, akdin icrası sırasında geçici şekilde temyiz kudretinden mahrumiyet sebebiyle nisbi butlan davası da mevzubahis olmaz. Ancak diğer taraf bizce ùç sene devam etmiş olması şartiyle boșanma dâvası açabilir.

\section{III - Hisimlik. Md : 112/3.}

Medeni kanun, bazı hısımlık derece ve nevilerini evlenmeye mutlak mâni saymıștır. Medeni kanunnun hısmlığı evlenme manii addetmesi, sıhhî mülâhazalardan ziyade ahlâkî düşüncelere müstenittir. Zira kaim valide ile damat veya gelin ile kaimpeder arasında usul fürûluk ve hiç bir kan hısımlığı olmadığı halde, medeni kanun, bir az sonra görüleceği üzere, bunlar arasında mutlak evlenme memnuiyeti kabul etmiştir.

\section{Evlenmeye mâni usul füru hisimiı̆ı :}

92 nci madde evlenmeye manî teşkil eden kan hısımlığını beyan ediyor. Madde, mevzu ile ilgisi nisbetinde şu suretle izah olunabilir:

Bir şahıs nesebi sahih olsun, gayri sahih olsun, füruu ile evlenemez. Binnetice, bir erkek, meșrû veya nesebi gayri sa-

(10) M. K. Md : 183. Mutlak butlan dâvasında zamanaşımı olmadığından evlenme, evlenme akdi sırasında daimî surette akıl hastalığına maruz bulunanlar akdedilen evlenme hakkında daima butlan dâvası açabilir. Lâkin akıl hastalığının şifa bulduğu raporla tevsik olunursa, artık mutlak butlan dâvası mesnu olma mak lâzımdır. Çünki bu halde akıl hastalığının daimî olmadığı anlaşllmış olur. Fakat evlenmeden evvel mevcut olan bu hastalik akitden sonra sürekli olarak üç sene devam etmiş ise, karşı taraf için boşanma sebebi teşkil eder. 
hih kızı ile evlenemiyeceği gibi, bir kadınla füruu arasındaki evlenme de mutlak butlanla malûl olur.

Bu hususta şu cihcte temas lâzımdır: Medeni Kanununun 92 inci maddesinin 1 No : lu bendi lafzina bakılacak olursa, bir șahsın nesebi teessüs etmemiș füruu ile evlenebileceği zehabı hâsıl olabilir. Bendin kanundaki gibi yazılmaması, daha basit ve daha șâmil șekilde kaleme alınması icab ederdi. Gerek İsviçre, gerek Türk kanunlarının bu hususda «Usul fürû arasında evlenme memnûdur» demeleri kâfi idi. Sahih ve gayrı sahih tefriki yapan bir hüküm koymaları münasib değildir. Zira bazan evliiik haricinde doğan çocukların babalarına karșı gaynsahih nesepleri bile yoktur. Madde o şekilde yazılarsa evlilik haricinde doğan bu gibi çocukların babaiarı ile evlenebilecekleri zehabı belirir. Halbuki buna imkân yoktur. "Gayrısahih nesep» tâbiri gayrı meșrû nesebi ifade eder. ise de, evlilik haricinde doğan her çocuğa şâmil olamayacağından, böyle bir zehaba mahal vardır. Hülâsa Medenî Kanunun 92/1 deki dar hükmünü yukarda izah edilen sebepden dolayı, geniș tefsire tâbi tutmak lâzımdır. Bu geniş tefsir neticesinde așağıdaki haller vârit olur :

1) Bir baba evlilik haricinde doğup da kendisine karşı gayrı sahih nesebi tanına veya babalık dâvası ile kurulmuş olan kızı ile evlenemeyeceği gibi, gayrı sahih nesebinin teessüsüne imkân olup da, henüz bu nesebi kurulmamış olan k1zı ile de evlenemez. Keza fiilî baba, evlilik haricinde edindiği ve tanınmasına imkân olmayan fiilî (içtimai) nesebli kızı ile de evlenemez.

2) Bir kadın meșrù yani evlilik içinde veya meșruiyet karineleriyle doğmuş olan yahut nesebi sonradan evlenme, yahut hâkim hükmü ile tashih edilerek sahih hale gelmiș olan bir oğlu ile evlenemeyeceği gibi, evlilik haricinde doğan gayrımeșrû (11) oğlu ile de evlenemez.

(11) İsviçre ve Türk Medeni kanunlarında evlilik haricinde doğan çocukların analarına karşı nesebleri doğumla sâbit ve bu çocuklar, babaya karșı mirascılığa muhalif olarak, analarına karŞl aynen sahih nesepli çocuklar gibi mirascı olur iseler de (M. K. Md : 443/1), bu çocuklar da anaya karşı gayn sahih ne- 
Evlâtlık, çocuk hükmünde ise de, fürû olmadığından, Evlâdedinme, mutlak ve hatta nisbî evlenme mânilerinden addedilmemiștir. Kanun evlâtlık münasebetini «butlanı mucib olmayan haller» matlabı altında saymıştır. Mad : 121/1,2. şu halde, bir kadın veya erkek her nasilsa evlâtlığı ile evlenmiş olsa, 121 inci madde mucibince, evlenme muteber, evlâtlik münasebeti zâil olur. 121 inci madde hükmü karşısında, evlâtlık râbıtasını hısımlık dolayısıyle evlenme mânii sayan 92 inci maddenin 3 üncü bendi hükmünün manâsı, münhasıran evlendirme memuruna evlâtlık râbıtası bâki iken evlenme akdini icra etmemek yetkisini vermiş olmasından ibarettir. Taraflar (evlâtlık ve evlât edinen) evlendirme memuruna 121 inci madde hükmünü beyan ile, 92 inci maddenin 3 üncü bendi hükmünün lüzumsuz olacağından bahisle akdin icrasını isteyemezler. Filhakika, evlâd edinenle evlâtlık arasindaki münasebet, ana baba ile çocuk arasındaki münasebete benzetildiğinden, evlâtlık râbıtası bakî iken bunların evlendirilmesi ahlâk ve âdâba aykırıdır. Fakat kanun, emri vâki haline gelmiş olan aile birliğini siyanet için, haklı olarak, 121 inci madde hükmünü kabul etmiştir.

\section{Civar hısumlığh, Md: $92 / 1$.}

A) Mezkûr bendin ikinci fıkrası, her çeşit kan kardeşleri arasında evlenme memnûiyetini zikrediyor. Ana baba bir, veya ana bir baba ayrí kardeşler yekdiğerleri ile evlenmişlerse, evlilikleri mutlak butlanla malûldür. Süt kardeşler arasinda evlenme memnuiyeti, Medenî kanuna göre mevzubahis değil ise de, islâm akide ve ahlâkına sâdık olanlar süt kardeşleri ile evlenmemektedirler. Zira Kur'anda süt kardeșle evlenmek kat'i surette men edilmiștir (12).

seplidirler. Bunun delilleri için : Şakir Berki, «Medeni Fukuku» (umumi esaslar, şahis ve aile hukuku), Ankara 1961, Sh: (252.). Bu hususda daha etrafl bilgi ve muntelif mucib sebepler için «Alman İsviçre ve Türk medenî kanunlarında evlilik dışında doğan çocuklar» adıyla 1962 yılında münteşir incelememize bakiniz.

(12) Bu husuda balcuniz: Sakir Berki - H. Håmide İslam hukukunun ana prensipleri «Kuranda Hukuk» Ankara, 1962. İkinci tab'l, sahife : 17 Memnuiyete ragmen evlenme vâki olsa, islâm hukuku bu evlenmeyi mutlak butlanla malúl addetmeyip 
B) Amca, dayı, hala ve teyze ile evlenme memnudur.

Medeni kanun, Alman sisteminden ayrilarak yukarda sayılan hısımlarla evlenmeyi men etmiștir. Bunlarla vâki ev lenme de mutlak butlanla bâtıl olup, keenlemyekûn değildir. Mezkûr şahısların çocukları ile evlenmek muteberdir. Amca, hala ilh... çocukları ile evlenilebilir.

3. Sihrî hisımlık. Md : 92/2.

Sthrî hısımlık, evlenme akdi dolayısıyle mevzubahis olup, sırf ahlâkî endişelerle ihdas olunmuştur. Bu hısımlık, eşlerin yekdiğerinin kan hısımları ile olan hısımlığıdır. Fakat her sıhrî hısımlık evlenme mânii değildir. Evliliğe mâni sıhrî hısımlık, ancak bir eşin usul füruu ile diğeri arasındaki hısımlıktır. Binnetice, karı kocasının usul ve füruu ile koca da karısının usul veya füruu ile evlenemez. Meselâ koca, Kaim vâlidesi ile veya karısının vaktiyle başka kocadan edindiği kızı ile (kocanın övey kızı) evlenemez (13).

Karı, kocanın, koca da karının kan hısımları olan civar hısımları ile evlenebilir. Meselâ kadın, kaim biraderi; Koca baldızı ile evlenebilir (14).

Üzerinde durulacak bir nokta şudur : sıhrî hısımlık, evlenme akdinden evvel mevcut veya evlilik esnasinda hâsıl olmuş olan eşlerin kan hısımları arasında mevzuubahistir. Yoksa karı veya kocanın evliliğin zevalinden sonra doğmuş olan fürûları ile sâbık karı koca arasında evlenme memnuiyeti olamaz. Zira bu fürû, evlenme mevcut değil iken, dünyaya gelmiștir. Bir misâl ile keyfiyeti aydınlatmak zaruridir: A ile B evlenirken birer füruuu vardı. A. ve B bu füru ile evlilik zeval bulsa bile evlenemez. Çünki bunlar A ve B evlenirken

gayrımevcut addetmiştir. Mutlak butlan sebepleri, islâm hukukunda bütün evlenme akitlerini keenlemyekûn, gayn mevcut kılar. Binnetice Ana oğlu ile, baba kızl ile, ağbey kızkardeşi ile her nasılsa evlenme akdi yapmış olsa, Kur'anı Kerim ve binnetice islâm hukuku, bu evlenmeleri butlan kararina kadar bile sahih bir evlenme olanak addetmez.

(13) Karı kocanın müşterek füruu ile evlenememek, usul fürúluktan doğan bir manî olup, sıhrî hısımlikla ilgili değildir.

(14) Bittabî bu imkân, evlilik zeval bulduktan sonra mevzuubahis olur. Aksi halde, çok evllik dolayısiyle eşlerin bunlarla evlenmesi mutlak butlan mucip olurdu. 
mevcut idiler. A, B boşanmış her birinden başka eşlerden fürûlar hâsıl olmuş ise, sâbık karı koca yekdiǧerinin bu kabil füruu ile evlenebilir. Lâkin bunlarla evlenmeden evvel, eski

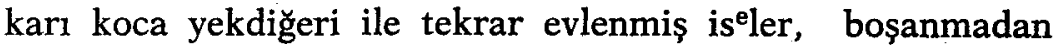
sonra edindikleri fürûlarla da sıhrî hısım olacaklarından, ikinci defa akdettikleri evlenme zâil olsa bile bu füru ile yine evlenemezler.

Sıhrî hısımlık aynen usul füru ve sair kan hısımlığı (civar hısımlığı) gibi hiçbir zaman zeval bulmaz. Çünki kanun, evlenme zâil olsa bile, sıhrî hısımlığın devam edeceğini beyan etmiș (Md: 18/2) ve 92 inci maddenin 2 inci bendi de, evlenme her ne sebeble zeval bulursa bulsun taraflardan her birinin yekdiğerinin usul füruu ile evlenemeyeceğini ifade ederek 18 inci maddenin evlenme mânileri bakımından tatbikatını yapmıștır.

4. Sun'î hrsımilk. Md : 92/3.

Evlâdlıkla evlâd edinen arasındaki hısımlığa sun'î hısımlık denir. Akdî hısımlık demek doğru olmayacağı gibi, müessesenin tesis eylediği nesebe de akdî neseb denemez. Zira, evlâdedinme akitle değil, Mahkemeden de izin alınmak suretiyle tekemmül eden resmî bir muamele ile vücut bulur.

Medenî Kanun, evlâd edinenle evlâtllk arasında evlenme memnuiyeti kabul etmiş ise de, bu memnuiyetin nisbî ve mutlak butlan davasına mahal veremeyeceğini de tensib eylemiştir. Bu cihete daha evvel yeteri kadar temas edilmiş olduğundan tekrara lüzum yoktur.

Evlâdlık râbıtası mevcut iken evlendirme memuru evlâtlıkla evlâd edinenin evlenme akdini icra edemez.

Evlâd edinme dolayssıyle memnuiyet, evlâd edinenle evlâtliğın füruu arasinda mevzuubahis olacak olan evlenmeye şâmil değildir. Binnetice, evlâdılk râbıtası devam ederken evlâd edinen evlâtlığın füruu ile evlenebileceği gibi, evlâtllk da evlâd edinenin füruu ile evlenebilir (15). Evlâtlı̆̆ın füruu-

(15) Alman medenî kanunu ise zannumizca haklı olarak evlâd edinme dolayisi ile evlenme memnuiyetini evlâd edinen ile evlatllğın füruuna da teşmil eylemiştir. Bu hususta bakınız: Şakir Berki, "Alman, İsviçre ve Turk medeni kanunlannda evlat edinme, Ankara, 1962. 
nun evlâd edinenin halefiyet tarikiyle mirasçısı olmasının ehemmiyeti yoktur.

Gerek İsviçre, gerek Türk Medenî kanunları, evlâd edinme dolayısiyle evlenme memnuiyetini evlâtlıkla evlâd edinenin evlenmesine münhasır kılmamıs, bunlardan birinin eși ile diğerinin evlenmesine de teşmil eylemiştir. Burada işarete değer ki, her iki kanunun bu hükmü lüzumsuz ve mesnetsizdir. Lüzumsuzdur, zira, evlâtlığın veya evlâd edinenin evliliği zeval bulmakdıkça bunlarla evlenme akdi esasen çok evlilik (poligami, poliandri) sebebiyle mutlak butlanla malûl olur. Mesnetsizdir, çünki, taraflar arasında evlenme, boşanma ve sair sebeplerle zeval bulsa, karılık ve kocalık sıfatı kalkacağından, kanunun zikrettiği evlenme memnuiyeti de mâna ifade edemez. Verilen hükmün neticelerini şöylece özetlemek mümkündür : Bir şahıs bir kadınla evlidir; evlenme zeval bulup bir erkeği evlâd edinmiștir; bu erkeğin (evlâtlık), evlâd edinenin sâbık karısı ile evlenmesi için hangi sebep mânidir ?. Vaktiyle bu kadının evlâd edinene karılık yapmıs olduğu ileri sürülecektir. Farz olunsun ki, aynı kadın, sâbık kocası evlâd edinmeden evvel müteaddit evlenmeler akd etse ve bunlar da zeval bulsa, evlâtllk mezkûr kadınla yine evlenemiyecek midir? Şüphesiz evlenme yine câizdir. Gerek İsviçre, gerek Türk Medenî Kanunlarının asıl evlâd edinme devam ederken evlâtlı̆̆ın füruu ile evlâd edinen arasında evlenme manii derpiş etmesi, bir mâna ifade eder, ve Roma hukukundan beri varagelen (Adoptio imitatur naturam) esasını tatmin edici bir hüküm teşkil eylerdi.

\section{§. III - MUTLAK BUTLAN DAVASI. Md :}

$\mathrm{Bu}$ paragrafda beş mesele üzerinde durulacaktır :

I. Mutlak butlan dâvasının vasıfları.

II. Dâvayı açabilecek olanlar.

III. Dâva hakkının tahdidi. Md : 114/1,2

IV. Dâvaya mahal olmadığı hal. Md : 114/3

V. Butlan kararı, selâhiyetli mahkeme ve usul. 


\section{I - Mutlak bưtlan dâvasımin vasıfları.}

Kanun, nisbî butlan dâvasında müruruzaman kabul etmiş olduğu halde (Md : 119), mutlak butlan dâvasında zamanaș1mindan bahsetmeniș, bu hususta kat'î bir sükût ihtiyar eylemiştir. Șu halde Mutlak butlan dâvasında müruruzaman yoktur. Nisbî butlanla mutlak butlan, mahiyet itibariyle ayrı olduğundan, kıyas da mümkün olmaz. Mutlak butlan dâvasında müruruzaman kabul edilmemesi, şu mülâhaza ile de kolayca teyid olunur : mutlak butlan sebepleri devam ettiği muiddetçe, âmme intizamı ve umumî vicdan ihlâl edilmekte berdevam olur. Bu itibarla mutlak butlan dâvasında zamanaşımının kabul edilmemiş olması, itiraz kabul etmez bir isabettir. Borçlar Kanunundaki umumî müruruzamanın bu hususta tatbik edilemiyeceği izahtan vâreste bir bedahattir (16).

Mutlak butlan, defi suretiyle dermeyan edilemez : mutlaka dâva açmak suretiyle evlilik ortadan kaldırılmış olmak lâzımdır. Bu esasın tatbikî önemi âşikârdır. Meselâ, esasen evli bir erkek bu evlilik devam ederken ikinci bir kadınla evlenme akdetmek imkânı bulmuş olsa, bu kadına karşı aile reisliğinin icab ettiği bütün vazifeleri yapmakla mükelleftir. Aksi halde kadın, bu vazifelerin ifası için dâva açsa, koca, bu dâvada evliliğin esasen poligami memnuiyeti dolayısiyle mutlak butlanla malûl bulunduğunu dermeyan suretiyle, kadının açtığı dâvayı red ettiremez. Bu netice, mutlak butlan sebebiyle malûl olsa bile, butlan kararı alınmıș olmadıkça, bâtıl evlenmelerin sahih evlenme gibi netice tevlit edeceğini natık kanun hükmü icabıdır. Hâkim dahi, sözü geçen misalde mutlak butlanı resen nazara alarak kadının talebini reddedemez.

(12) Her ne kadar Medenî kanunun 5 inci maddesi, Borçlar hukukunda akitlerin sukutuna dair olan umumî hükümlerin Medenî hukukda da cârî olduğunu beyan etmekde ise de, mutlak butlanın özel mahiyeti ve kanunun mutlak butlan davâsında müruruzamandan bahsetmemesi, buna mukabil nisbî butlan davâsinda müruruzamanı ihmal etmemiş olması 5 inci madde hükmünün mutlak butlan davasında Borçlar hakkında kabul edilmiş olan umumî müruruzaman müddeti olan 10 senenin tatbik edilemiyeceği için kâfi birer sebeptir. 


\section{II — Butlan dâvasını açacak olanlar. Md : 113}

Maddeye göre, butlan dâvasını açacak olanlar şunlardır :

1. Savcl.

2. Taraflardan her biri.

3. Diğer alâkalılar.

\section{Save1.}

Mutlak butlan dâvasını halkdan her şahıs açamaz. Ammeyi halk namına savcı temsil ettiğinden, mutlak butlan dâvasını savcı ikame eder. Fertler, savcıyı tahrike haklıdır; yani mutlak butlanla malûl bir evliliğin mevcudiyetinden haberdâr etmeye mezundur. Meselâ bir şahıs kız kadeşiyle evlenmiş veya bir kadın damadi ile, evlilik zeval bulmuş olsa bile, evlenme akd etmiş olsa, buna vâkıf olan herkes, savcıyı keyfiyetten haberdar etmeye selâhiyetlidir. Amme velâyetini temsil eden hâkimler, mutlak butlanı resen nazara alamaz iseler de savcıyı tahrik edip, bu dâvanın ikamesini temine mezundurlar. Şuna da işaret edilmelidir: Hâkimler, mutlak butlanla malûl bir evliliğe müstenit hak iddialarını ve meselâ kadının kocadan nafaka talebine dair olan dâvaları, mutlak butlan dâvasının neticesine tâlik edemezler; mahkemelerin yapacağı is mutlak butlanla bâtıl olsa bile evlenmeden doğan hak taleplerini intaçtan ibarettir. Keza mahkemenin mutlak butlanla malûl bir evlenmede taraflardan birinin açtığı boşanma dâvasını mutlak butlan dâvasına çevirmeye yetkisi yoktur. Yani hâkim böyle bir boşanma dâvasını, batıl evlenmelerde boșanma dâvası ikamesine mahal olmıyacağı mucip sebebiyle müddeabihten başkasına hükmedemez. Zira boşanma başka, mutlak butlan dâvası başkadır (17).

\section{Tarafların dâva hakkı :}

113 üncü madde bizzat taraflardan her birinin bu dâvayı açabileceğini sarih surette kaydetmiş olmamakla beraber, "alâkadarlardan her biri dahi butlan dâvasını ikame edebilir» şeklinde şâmil bir ibare kulanmıştır. Bu ibareden, butlan dâ-

(17) Mutlak butlanla malû bir evlenme boşanma kararı ile de zeval bulabilir. Şakir Berki, Medeni hukuk, sa 171. 
vasının bâtıl evlenme ile miras hakkı ortadan kalkan, yahut bu evlenme sebebiyle mirasdaki payı azalacak olan mirasçılar tarafından ikame edilebileceği anlaşıldı̆̆ı gibi, bâtıl evlenmenin taraflarını teşkil eden karı kocanın dâva ikame yetkisi de anlaşılmaktadır. Keyfiyete bir kaç misal vermekte fayda vardir :

Esasen evli bir şahıs, bu evlilik devam ederken başkası ile evlense, diğer taraf suiniyetli olsa, yani kendisi ile evlenenin evli olduğunu bilerek evlenmiş bulunsa bile, butlan dâvasını ikame edebileceği gibi, ayn yetki evli iken tekrar evlenen taraf içinde mevcuttur. Mahkeme suiniyeti nazara alarak açılan mutlak butlan dâvasını red edemez. Aksi hal âmme intizamının ihlâlinin devamını tensip mânasına gelirdi.

Bir şahıs ana veya babası ile her nasılsa evlense, bu evlenmede her iki taraf hüsnüniyetli olsa, her birinin mutlak butlan dâvası ikamesine hakkı olduğu gibi, suiniyetli olsalar dahi aynı yetkiyi hâiz olacakları tabiidir.

Daimî akıl hastalığına müptelâ iki şahıs evlense, mutlak butlana vâkıf olan vasîlerinin bu dâvayı açmaya hakkı olur mu ?: Bizce kanunî mümessiller butlan dâvasında kanunun kasd ettiği alâkalıdardan olmadıklarından, cevap menfî olmak lâzımdır. Ancak kanunî mümessillerin savcılığı tahrik etmek suretiyle hareket etmeleri câizdir. 113 üncï maddedeki "alâkalılardan her biri» tâbirine tarafların kanunî mümessilleri dahil edilemez. Çünki "alâkalılar» dan maksat, butlan hükmünden menfaat sağliyacak olan kimselerdir. Bunlar evvelâ bizzat taraflar, sâniyen bunların mirasçllarıdır. Binnetice Hazine vekíli dahi mirasçı sıfatiyle butlan dâvasını açabilir. Ancak bunun için başka mirasçı olmamak lâzımdır.

Nisbî butlan dâvası ile. mutlak butlan dâvası arasında, dâvayı açacak olanlar bakımından da fark vardır: mutlak butlan dâvası, kaydedildiği gibi, her iki tarafça açlabileceği halde, nisbî butlan dâvasını yalnız nisbî butlan sebebine maruz bulunan karı veya koca ikame edebilir. Meselâ bir kadın hatâ ile evlenme akdeylemiş olsa, kocası bu hatâyı bahane ederek evliliği nisbî butlan dolayısiyle feshettiremez. 
Keza 127 nci madde, nisbî butlan dâvasında mirsaçlara ancak açılmış olan dâvayı tâkip yetkisi vermektedir. Halbuki mutlak butlan dâvasında tarafların mirasçıları, açılan dâvay1 tâkip yetkisine değil, bizzat dâva açabilme hakkına sahiptir; dâva açılmamış olsa bile miras sebebiyle alâkalı olanlar re'sen dâva açabilirler. Bu hususu diğer alâkalıların dâva hakkı bahsinde şimdi icab eden şümul ile incelemeye çalıșacağız.

\section{Diğer alâkalılarin dâva hakkı :}

Nisbî butlan dâvasında diğer alâkalılar açılan dâvayı devama haklı oldukları halde, mutlak butlan dâvasinda diğer alâkalılar tâbiri ile ifade olunan şahıslar, taraflar dâva açmasalar bile, dâvayı ikame etmek hakkına sahiptirler. Diğer alâkalılardan maksad, hâtıl evlenme dolayısiyle mirasdaki menfaatleri haleldar olan, mirasa gelemeyen veya mirasdaki payları azalan herkestir. Mansup mirasçıların dahi butlan dâvasını açmaya hakkı vardır. Meselâ, hiç kanunî mirasçısı olmayan bir șahıs, diğer bir şahsı miras mukavelesi ile bütün terekesi için mansup mirasçı tâyin etse, bilâhare veya mirasçı nasbından evvel, mutlak butlanla malûl bir evlenme akdeylemiş bulunsa, mansup mirasçının bu evlenme hakkında mutlak butlan dâvası açması menfaati icabındandır. Aksi halde kendisine nakledilmiş olan bütün terekeye değil, batıl evlenme ile hayatta kalan eşin hissesi çıktıktan sonra kalacak olan tereke miktarını iktisab edebilirdi. Zira, mutlak butlanla malûl bir evlenme, butlan kararına kadar sahih evlenmenin bütün hükümlerini tevlit edeceğinden, butlana karar verilmeden evvel vefat halinde bâtıl evlenmede taraf olan karı veya koca, hayatta kalan eş olarak mirasçı olacaktır.

Hazine dahi alâkadar sıfatiyle mutlak butlan dâvasını açabilir. Meselâ hisım olarak kanunî hiç bir mirasçısı olmayan bir şahıs mutlak butlanla malûl bir evlenme akdetse, savcı mutlak butlan dâvası açmamış olsa bile Hazine vekilinin miras hakkı bakımından dâvayı ikameye hakkı olur.

Yalnız intifa hakkı sahibi olan mirasçıların da aynı dâvayı açamamaları için hiç bir sebep yoktur. Büyük ana, büyük babaların ana ve babaları Isviçre ve Türk Medenî Kanunlarında yalınız intifa hakkına sahip mirasçılardandır. (Türk Md. 
K. Md : 442/2,3) Yukardaki misaldeki dâvayı bunlar dahi açabilirler; aksi halde, hayatta kalan eșin eşin mevcudiyeti sebebiyle terekenin rakabesine Devlet ve binnetice bir kısmin intifaina da mezkûr usul sahip olamazlar.

Mutlak butlan sebebiyle miras hisseleri azalacak olanlarun da butlan dâvası ikame etmeye hakları vardır : Meselâ, bir şahsın iki çocuğu vardır; bu şahıs kaim vâlidesi ile evlenmiştir. Butlan kararı alınmadan ölse, kaim vâlide de hayatta kalan eş olarak hisseye sahip olacak ve çocukların mirasdaki hissesi azalacaktır.

Mamafih işaret edelim ki, mücerret mutlak butlan dâvası ikame edilmiş olmakla, mezkûr alâkalıların menfaatleri temin edilmiş olamaz. Butlan kararı verilip, kesinleşmiş olmalıdır. Aksi halde, bâtıl evlenme doğrudur. Karı veya koca karardan evvel vefat etse, diğeri, hayatta kalan eş sıfatiyle mirasçı olur.

\section{III - Dâva hakkının tahdidi. Md : 114/1,2.}

114 üncü maddenin 1 ve 2 nci fikraları, mutlak butlan dâvasında savcının selâhiyetini ref ediyor. Bu fikralardaki hallerde mutlak butlan dâvası resen ikame edilemez. 1 inci fikra ile ikinci fıkra hükümleri ayrı ayrı tetkik edilmek lâzımdır :

1 inci fıkra dâva açma yetkisini yalnız savcıdan kaldırmıştır. Alâkadarlardan her birinin dâva ikamesine müsaittir. Binnetice, mutlak butlanla malûl bir evlenme ölüm veya boşanma ile zâil olsa, aşağıdaki neticeler hâsıl olacaktır :

Mutlak butlanla malûl evlenme ölüm ile zeval bulmuş ise, hayatta kalan eş, aynen sahih evlenmedeki eş gibi miras hissesini alır. Zira butlan kararı alınmadan her bâtıl evlenme sahih evlenme gibi netice tevlit eder. Bilâhare verilecek olan butlan kararı hayatta kalan eșin miras hukukunu ihlâl edemez. Çünki, miras hakkı, miras henüz paylaşılmamış olsa bile, murisin ölümü anında hakkı mükteseb olmuştur. Binnetice, tereke hâkimi ölümden sonra açılacak olan butlan dâvasının neticesine intizara mecbur olmaksızın hayatta kalan eşin payinı verecektir. 
Ölümle zeval bulmuş olan mutlak butlanla malûl bir evlenme hakkında butlan dâvası açarak butlan kararı almanın tatbikî önemi ikịir :

1) Hazine bakımından, dul maaşının verilmemesini temin.

2) Evliliğin zevaline rağmen kadının evlenmekle iktisap ettiği ahvali şahsiye ile ilgili bazı neticeleri izale. bir de aile şerefini vikaye. Meselâ biri kız kardeşi ile evlenmiș, evlilik ölümle zeval bulmuş; zevale rağmen hayatta kalan kadının erkek kardeşinden dul kalan kadın hüviyetinde bulunması ahlâk ve âdabı yine rencide etmeye devam edeceğinden butlan kararı zarurî olur.

Hazine vekili butlan dâvasını bizzat açabilir. Çünki buradaki butlan dâvası, savcılığın açacağı butlan dâvası gibi âmme intizamını muhil bir hâdisenin izalesine matuf olmayıp, sırf Hazinenin maddî külfetten siyaneti için mevzuubahistir. Bu itibarla Hazinenin, gayesi bundan ibaret olan butlan dâvasını ikame için savcılığı tahriki câiz olmıyacağı gibi, esasen savcılık da 114 üncü maddenin birinci fıkrası hükmüne dayanarak butlan dâvasını ikame edemez. Hazineyi mamelekî bakımdan temsil edecek olan Hazine vekilleri olup, savcılık değildir.

Evlilik zeval bulmadan evvel ikame edilecek olan butlan dâvasında müruruzaman olmadığı gibi, evliliğin zevalinden sonra ikame edilecek olan mutlak butlan dâvalarında da müruruzaman yoktur.

Evliliği mutlak butlanla mâlul bulunmayan birinci kadının, müșterek kocalarının ölümü dolayısiyle dul kalmış olan ikinci kadın hakkında mutlak butlan dâvası ikameye hakkı olmamak lâzımdır. Zira, dul maaşları ayrı ayrı tahakkuk ettirilir; yani ikinci kadın, birinci kadına tahsis edilecek olan dul maașının yarısına hak kazanmaz (18). Yarı yarıya istihkak ancak mirasda mevzuubahis olur. Ölüm ile miras açılıp, ikinci kadın hakkında miras hakkı, hakkı müktesep teşkil edeceğineden, birinci kadının bu bakımdan da butlan dâvası ikame etmesi düșünülemez. Ancak, ahvali șahsiye bakımmdan ikinci

(18) Zira dul maaşlarından maksat dul kadınların nafakasını temindir. Nafaka hükmünde olan maaşın ikiye bölünerek verilmesi nafakanin mahiyeti ve gayesi ile kabili telif olmaz. 
kadının müteveffa kocanın soyadını taşımaması için dâvanın birinci kadın tarafından da açılabileceği düşünülebilir.

114 üncü maddenin 2 nci bendi, mutlak butlan dâvası ikamesi hakkını daha ziyade tahdit etmiş ve dâva yetkisini yalnız karı veya kocaya bahşetmek suretiyle, diğer alâkalıların dâva hakkını kaldırmıștır. Fıkra aynen şöyledir : "Mümeyyiz olmamanın veya bir akıl hastalığı ile malûliyetin zevali halinde, evlenmenin butlanı ancak karı veya koca tarafından dâva olunabilir." (19).

Bu hükümle 114/1 deki hüküm arasındaki ilk fark, 114/1 deki dâvanın evliliğin zevali halinde mevzuubahis olmasına mukabil 2 nci bendde, evlilik devam ederken dâva hakkının mevzuubahis oluşudur. İkinci benddeki dâva ile nisbî butlan dâvası arasındaki fark, nisbî butlan dâvasının müruruzamana tâbi olmasından ibarettir.

114/2 deki dâva evliliğin zevali halinde de açılabilir: A, akıl hastası olan B ile evlense, hastalık zâil olmadan veya olduktan sonra A ölse, B nin mutlak butlana hüküm alması yine mümkündür.

Evliliğin boşanma ile zevali halinde durmak lâzımdır : Bu halde de umumiyetle ölümle zevale dair butlan dâvası esasları carîdir. Mutlak butlan ile malûl bulunan bir evlilik, butlan kararından evvel boşanma ile de zeval bulabilir. Hattâ mutlak butlan sebebi, boşanma hükmünden sonra öğrenilmiş olabilir. Meselâ iki kardeş, kardeş olduklarını bilmeden evlenseler, boşanma ile zeval bulmuş olmasına rağmen, evlenmenin butlanına karar. alınarak boşanmanın neticeleri izale edilebilir. Çünki, boșanma ve neticeleri, malûl olmakla beraber, mevcut (butlan kararına kadar sahih) bir evlenmeden doğmuştur. Bir misal fuzilî olmaz:

(19) Bu hüküm, nisbî butlan davâsı ile değil, mutlak butlan davâsı ile alâkalıdır. Akdin icrası sırasında daimî suretde akul hastalığına müptelâ olan bir şahısla evlenilse, bu hastalık evlilik akdinden sonra 10 sene devam etse, diğer taraf hastalğın şifa bulmuş olmasına rağmen mutlak butlan davâsı ikame edebilir. Savcı veya sair alâkalıların davâ hakkı yoktur. 
İki kardeşin mutlak butlanla bâtıl evlenmesi boșanma ile zevâl bulsa, Hâkim bir tarafa nafaka hükmetse (zaruret nafakası Md: 144), diğer taraf bu nafaka mükellefiyetinden kurtulabilmek için boşanma hükmüne rağmen evlenmenin butlanına karar alabilir. Butlan kararnndan sonra nafaka mükelelfiyeti kalkar, Meselâ nafaka müddetinin bitimine üç ay kala butlana karar verilse, lehine nafaka hükmedilen taraf üç aylık nafakayı isteyemez. Çünki butlan kararı, boşanma hükmünü iptal eder.

Sair mutlak butlan hallerinde de yukarıdaki misale kiyasen hükmetmek lâzımdır.

\section{IV - Dâvaya mahal olmadığı hal. Md : 114/3.}

Mezkûr fıkra yalnız bir halde mutlak butlanla bâtıl evlenmenin savcilık, alâkadarlar ve taraflarca iptal ettirilemiyeceğini derpiş ediyor. İahına geçmeden evvel hükmü aynen kaylt etmek zarurîdir : «Evli iken yine evlenen bir kimsenin bu evlenmesine butlan hükmü verilmeden evvel, vefat vesair sebeplerle evvelki evlenme zail olmuș olur ve yeni evlenmede de diğer taraf hüsnüniyet sahibi bulunur ise, butlana hükmolunamaz».

Bu hüküm üzerinde de yeteri kadar durmak zaruridir : Esasen evli bir erkek, bu evlilik devam ederken, bașka bir kadinla her nasılsa evlendirme memuru huzurunda icap eden merasim şartları dahilinde tekrar evlenmiş olsa, veya, esasen evli bir kadın aynı şekilde ikinci bir erkekle evlenme akdetmiş bulunsa, birinci halde poligami, ikinci halde poliandri memnuiyeti dolayssiyle mutlak butlanla bâtıl olan ikinci evlenmeler prensip itibariyle mutlak butlan dâvası ile ortadan kaldırılabilir. Fakat 114/3, bunun bir istisnasını iki șartla kabul etmiştir :

1) Birinci evlilik ölüm, boşanma yahut nisbî veya mutlak butlan kararı ile veya 127 nci maddedeki fesih (20) sebep-

(20) M. K. Md. 120, kanunî mümessilin, ana baba veya vasinin fe sih hakkina dairdir. 
lerinden biri ile ortadan kalkmalıdır. Bu halde poligami veya poliandri fiilen devam etmiyeceği için, âmme ahlâk ve vicdanını muhil durum da ortadan kalkmış olacağından, ikinci evliliğe birden ziyade evlenme memnuiyeti dolayısiyle taarruza lüzum yoktur. Medenî Kanun bu hususta «mani zâil oldukta memnû avdet eder» șeklinde ifade edilen prensibin tatbikini yapmıștır. Kaydedelim ki, ikinci evlilik hakkında mutlak butlan kararı verilmemesi için bu evliliğin yalnız fazla evlilik dolayısiyle bâtıl olması icap eder; diğer mutlak butlan sebeplerinden biri ile de malûl ise, artık 114/3 tatbik edilmez; butlana yine hükmedilir. Meselâ evli bir erkek bu evlilik devam ederken, kız kardeşi, veya kaim validesi ile evlenmiş, bu evliliğin butlanına karar verilmeden evvel birinci evlilik zeval bulmuș olsa, ikinci evlilik hakkında poligami memnuiyetinden dolayı butlan davası açılamaz ise de, evlenmeye mâni hısımlık sebebi ile butlan dâvası ikame edilebileceği tabiidir.

2) İkinci evliliğin poligami veya poliandri sebebiyle izale edilememesi için 114/3, ikinci bir şart derpiş ediyor ki, o da esasen evli olan bir şahısla evlenenin, yani ikinci evlenmede diğer tarafı teșkil eden karı veya kocanın hüsnüniyetli olması, yani evlendiği kimsenin esasen evli olduğunu bilmemiş bulunmasıdır. Aksi halde ilk evlilik zâil olsa bile, ikinci evlilik hakkında çok evlilik sebebiyle yine mutlak butlan kararı alınabilir.

Hüsnüniyetin, akdin icrası sırasında bulunması lüzumu izahtan varestedir. Diğer taraf evlendikten sonra, evlendiği şahsın esasen evli bulunduğunu öğrense, bu vukuf 114 üncü maddenin 3 üncü bendinin tatbikine mâni olamaz; yani birinci evlilik zeval bulsa ikinci evlilik, diğer tarafın keyfiyeti sonradan öğrenerek suiniyetli hale gelmiş olduğu bahanesi ile iptal olunamaz. Çünki hüsnüniyet hakkın doğumunda aranır, hak doğduktan sonra mevzubahis olmaz. (M.K. Md:2) (21).

İkinci evlilikde diğer taraf, yani esasen evli bulunan şahısla evlenen karı veya koca, akıl hastası idi ise, böyle kimse-

(21) Diğer taraf evlenme akdi sırasında hüsnüniyetli olduğundan, akd ettiği evlilik dolayısiyle $114 / 3$ deki hükümden faydalanma imkânı onun lehine kanunî bir hak olarak doğmuştur. 
lerde temyiz kudreti bulunmadığından hüsnüniyet ve suiniyet aranmaz. Șu halde yalnız bu ihtimale münhasır olmak üzere ikinci şart aranmaksızın 114/3 ün tatbikine mahal olur. Ancak mezkûr ihtimalde ikinci evlilik dâimi surette akıl hastalığ sebebiyle (22) iptal edilir; birinci evlilik zâil olunca birden ziyade evlilik sebebiyle hiç bir veçhile iptal edilemez. Çünki, kaydedildiği üzere, akıl hastalarında hüsnüniyet ve suiniyet mevzuubahis olmaz.

\section{V - Butlan kararı, selâhiyetli mahkeme ve usul.}

\section{Butlan Kararı. Md : 124.}

Medenî Kanun bu maddede, mutlak ve nisbî butlana dair müşterek neticeleri formüle etmiştir. 124. maddenin birinci fıkrası prensibi şöyle vaz ediyor : «Evlenmenin butlanı, ancak hâkimin kararı ile hüküm ifade eder».

Butlan kararı ile ilgili bu ilk esasın manası şudur : Evlenme akd edildikten sonra, mutlak butlan sebebine evlendirme memuru vâkıf olsa, artık aile birliği emri vâki haline gelmiștir; akdi iptal edemez. ve kayitlarda akdin iptal edildiğine dair hiç bir değișiklik yapamaz; Nüfus memurluğu da gerek re'sen gerek hâkimden başka bir memurun emri ile bâtıl evlenmeye müdahale ve sicilde en ufak değișiklik yapamaz. Evlilik gibi toplumun temel taşı olan aile birliğine son verebilmek için, keyfiyetin mahkemece incelenmesi ve butlan kararının mahkemeden sadır olması lâzımdır.

\section{Butlan davâsında selâhiyet.}

Mutlak butlan davâsında selâhiyetli mahkeme 128 inci madde delâletiyle boșanma davâsındaki gibidir. Zira mezkûr madde, bâtıl olan evlenmeler matlabı altındaki dördüncü fasılda fesih, nisbî ve mutlak butlan davalarında müşterektir. Diğer cihetten, mutlak butlan davâsında selâhiyete dair hususî bir hükme tesadüf olunmamaktadır. Binnetice, aynı madde mutlak butlan dâvasında selâhiyet hakkında da

(22) Akdin icrası anında geçici suretde temyiz kudretinden mahrumiyet, nisbî butlan sebebidir. Zaman aşımı müddeti içinde nisbî butlan davası açılmamış ise, 114/3 yine kabili tatbik olur. 
tatbik olunacaktır. Mamafih, mutlak butlan davâsında selâhiyetli mahkemeyi tâyin ederken aşağıdaki tefrik nazara alınmak lâzımdır :

1) Davâ, savcı tarafından açılacaksa, boşanma davâsında selâhiyetli mahkemeyi tâyin eden $136 \mathrm{mncl}$ maddenin, 128 inci madde delâletiyle kıyasen tatbikine imkân yoktur. Bu madde, Usul kanununun 9 uncu maddesinde derpiş olunan selâhiyet kaidesine bir istisna koymaktadır. Usul kanunu, her davânın davâ ikamesi sırasında davâlının medenî kanun gereğince ikametgâhı mahkemesinde ikame edileceğini beyan ettiği halde, Medeni kanun 136 nncı maddesi davâcının ikametgâhı mahkemesini yetkili kılmakla Usul kanununun 9 uncu maddesindeki esasa bir istisna vaz eylemektedir.

136 incı madde mucibince, savcının açacağı butlan davâsında savcının ikametgâhı mahkemesi nazara alınamaz. Zira savcı, bu davâyı kendi namına ikame etmemektedir. Şu halde mutlak butlan davâsını savcının açacağı hallerde Usul kanunundaki esas tatbik olunmak lâzımdır. Yani savcı tarafından açılacak olan davânın karı kocanın davâ sırasındaki ikametgâhları asliye mahkemesinde açılması icab eder. Kadın, ayrı ikametgâh ittihaz etmiş ise (23), savcı muhtardır, dilerse kocanın, isterse karının ikametgâhı asliye mahkemesinde davâ ikame olunabilir (24).

2) Mutlak butlan dâvasını karı kocadan birinin veya sair alâkalıların açacağı hallerde, selâhiyetli mahkeme, 128 delâ- $^{-}$ letiyle $136 \mathrm{incl}$ maddedeki mahkemeden ibarettir.

(23) Ayrnlığa hükmedildiği; boșanma davâsı ikame olunduğu tarihden itibaren boşanma hükmüne kadar; Müşterek hayatın tatilini mucib hallerde kadının mahkemeden izin alarak ayrı ikametgâh ittihaz eylediği üç halde, evli kadının ikametgâhı kocanın ikametgâhı sayılmaz. Bu haller haricinde, evlenme mutlak butlanla malâl olsa bile, kadın kocanın ikametgahına tabidir. Bu hususda bakınız: M. K. Md : 21/2; 137.

(24) Savcının mutlak butlan davâsını, meselenin amme intizamı ile ilgisi bulunduğu mülâhazası ile her asliye mahkemesinde açması doğru olamıyacağı gibi, icab da etmez. Zira, butlan davâlanı mürurzamana tâbi olmadığından, davânın mürurzaman sebebiyle açılamıyacağı endişesi dé gâlip gelerek, isticale lüzum kalmaz. 


\section{Butlan davâsinda usul.}

Mutlak butlan davasında mahkeme, mutlak butlan sebebi sâbit olunca, butlan kararı vermiye mecburdur. Mutlak butlan sebebinin sübutu için hâkim tahkikata mecburdur; yemin teklifi câiz olamaz. Bu bakımdan boșanma davasındaki muhakeme usulïne ait olan esas câridir. Lâkin boşanma davasının diğer hususiyetleri, mutlak butlan davasında hiç nazara alınamaz. Meselâ mutlak butlan sebebi sâbit olmuş iken, mahkeme mutlak butlanla mâlûl evliliğin senelerce devam etmiş olduğunu ve çocuklar doğduğunu, taraflarnn normal ve pek mes'ut aile hayatına sahip bulundukları gibi hususları nazara alarak, butlan sebebine rağmen butlan davasinı red edemeyeceği gibi, poligami veya poliandri memnuiyetinden dolayı bâtıl olan ikinci evlilik hakkında ayni mülâhazalarla birinci evliliğin zevaline intizaren ayrılığa veya müşterek hayatın tatiline müncer olan karar veremez. Çünki bütün bu hallerde hâkim âmme intizamına aykırı bir evliliğin devamını tasvip eylemiş olurki, buna yetkisi yoktur; bilâkis mahkemeler, amme intizamını siyanetle mükelleftir.

Hâkim, mutlak butlan davasında ikrarı da nazara alamaz; eşler yekdiğerinin evlenemez derecede hısımı olduklarını ikrar etseler, hâkim, bu ikrara itibar ederek mutlak butlan sebebinin sübutuna ve mutlak butlana karar veremez.

Mutlak butlan davasinda yalnız mahkemenin yemin ve ikrarı nazara alamayacağı, bu davaya boşanmaya dair usulï muhakemenin tatbik edileceğinden değil, mutlak butlan sebeplerinin hepsinin yeminden ve ikrardan başka delillerle ispatı icap ettiğindendir. Bu deliller, mutlak butlan sebeplerinin mahiyetine göre resmi sicil, şahit veya Tıbbı Adli raporudur. Daimi akıl hastalığı sebebiyle butlan davâsında rapor lâzımdır. Şu halde kanunda mutlak butlan dâvasında boşanmaya dair usulün tatbik edileceği yażılı olmasa idi bile butlan sebeplerinin mahiyeti icabından olarak ikrar ve yemin bizzarur nazara alınamazd.

\section{§. IV - BUTLANIN HÜKMÜ : MD : 124/2; 125, 126.}

\section{I - Genel prensipler.}

Evelneme mutlak butlanla malûl olsa bile, butlan kararına kadar sahih bir evlenmenin bütün hukukî neticelerini 
tevlit eder. Kanunun, bu mealdeki hükmü kısaltılarak şöyle de ifade edilebilir: "bâtıl evlenme butlan hükmüne kadar sahihtir». Binaenaleyh, karı kocanın yekdiğerine karşı vazifeleri, evlenmenin umumi hükümleri ve hatta mal rejimlerine dair esaslar, mutlak butlanla malûl evlenmelerde de aynen câri olduğu gibi, çocukların nesebi sahihdir (25), ve çocuklarla ana baba arasındaki münasebet, yani velâyet, tedip hakkı, tahsil, terbiye, iaşe masrafları çocuğun temsili ilh... hep sahih evlenmedeki gibidir.

124 üncü maddenin 2 inci fikrasındaki hükmün tatbikî iki neticesi daha vardır :

1) Mutlak butlanla malûl evlenme butlan kararına kadar sahih evlenmeden farksız addedildiğinden, taraflar sahih evlenmeye son veren boşanma müessesesinden faydalanırlar. $\mathrm{Bu}$ cihete etüdün başlangıcında yeteri kadar temas edilmiști.

2) Mutlak butlanla malûl evlenme sahih evlenmeden farksiz olduğundan, butlan kararından evvel taraflardan biri ölse, diğer taraf, hayatta kalan eşin mirastaki hukukuna sahiptir. Mutlak butlan davâsı açıldıktan, fakat butlan kararı verilmeden ölüm vâki olsa, , hüküm aynıdır. Sonradan verilecek olan butlan kararı, hayatta kalan eşin mirastaki müktesep hakkın izale edemez. Bu ciheti de daha evvel bilvesile izah etmiştik. Taraflardan biri temyiz safhasında ölse, hayatta kalan eş yine mirascı olur. Zira, butlan kararından maksat kesinleșmiş olan hükümdür.

Tashihi karar müddeti de usul kanununa göre muhkem kaziyenin teşekkülïi için geçmesi lâzım bir müddet olduğundan tashihi karar müddetinin bitiminden evvel ölüm vâki olsa, hayatta kalan eş, yine mirascı olur.

(25) M. K. Md : $125 ; 241$; bu sonuncu madde, evlilik mevcut iken doğan çocuğun babasının koca olduğunu, beyan ile keyfiyeti teyid ediyor. Mutlak butlanla malcil bir evlenme, mevcut ve butlana kadar sahih evlenme olduğundan böyle bir evlenme mahsulü olan çocuk da meşru nesep karineleri içinde doğdukca, sahih neseplidir. 


\section{II - Butlan kararmmn çocuklarla ilgili neticeleri Md : 124 ve $125 / 1$.}

124 üncü maddenin ikinci fıkrasına göre mutlak butlan ile malûl olan evlenme, butlan hükmüne kadar sahih ve evlilik içinde doğan çocukların nesebi de meşrû addedildiğinden, mutlak butlanla bâtıl evlenmeden doğan çocuklar ana ve babalarına karșı meşrûdur. Nesebin reddine dair olan esaslar bakidir. Yani çocuk mutlak butlanla bâtıl olan evlilik devam ederken doğmuş olmakla beraber, kocanın baba olmadığını ispata hakkı vardır. Bu hususta 242 ve müteakip maddeler tatbik edilir. Çocuğun evlilik içinde ana rahmine düşşmüs olmasina lüzum yoktur. Evlenmeden evvel cinsi münasebet vâki olsa ve ana baba sonradan mutlak butlanla malûl olsa bile evlenme akdetmiş iseler, bu evlilik içinde doğan çocuğun nesebi yine sahihdir. Hattâ çocuk evlenme akdinden evvel doğsa, bu sefer, nesebi, ana babanın sonradan evlenmesi ile nesep tashihi dolayssı ile sahih olur. Zira mutlak butlan kararına kadar sahih addedildiğinden, mutlak butlanla bâtıl evlenme akdi de nesep tashihine vesile olur ve bu tashih, hakkı müktesep teșkil eder, yani butlan kararı ile sakıt olmaz.

Çocuk mutlak butlanla bâtıl olan evlenmeden evvel ana rahmine düssse ve ana babası evlenmiș olsa, fakat çocuk henüz doğmadan evvel butlan kararı verilse, gayrı meşru olur. Böyle bir çocuğun ana ve babasının sonradan yek diğeri ile evlenmiş oldukları göz önünde tutularak nesep tashihinden faydalandırılmak suretiyle sahih nesebli addedilemiyeceği tabii dir. Zira nesep tashihi, çocuk, evlenme vâki olmadan doğduktan sonra ana babasının yekdiğeri ile evlenmesi halinde mevzubahistir.

125 inci maddenin 2 inci fıkrası, mutlak butlanla malûl evlilik içinde doğan veya böyle bir evlilikte ana rahmine düșüpte, butlan kararından sonra dünyaya gelen meşrû çocukların ana ve babaları ile olan münasebetlerinin boşanma halinde çocukların durumuna ait esaslarla tanzim edileceğini beyan ediyor. Yani mahkeme çocuğu ister anaya, ister ba- 
baya tevdi eder, velâyet de ona göre taayyün eder (26). İștirak nafakası ilh.. gibi hususlardan da çocuk, aynen boşanmadaki gibi faydalanır.

\section{III - Butlan kararının karı ve koca hakkındaki hükümleri}

\section{Md : 126.}

Evlilik mutlak butlanla malûl olsa bile, butlan kararına kadar sahih evlenme addedileceğinden, 126 incı maddede tasrih edilmemiș olmakla beraber, karı ve koca «evlenme kișiyi reşit kılar» kaidesinden istifade ederler (27). Ancak butlan kararından sonra taraflar henüz rüște vâsıl olmamışlarsa evlenmekle rüşt bunlar hakkında müktesep hak teşkil edemez.

$\mathrm{Bu}$ hususu bazı misaller ve izahatla açılamak zaruridir : Esasen evli bir erkek, henüz 15 şayındaki mümeyyiz bir kızla evlenmiș olsa, poligami yasağı dolayısıyle mutlak butlanla malûl olan bu ikinci evlilik, butlan kararına kadar sahih evlenme gibi addedildiğinden, bu kadın da rüşt iktisap etmiş olur. Fakat kadın henïz 18 yaşını ikmal etmeden butlan kararı verilse, evlenmekle edindiği rüsşt devam etmez. Ancak evlilik müddetinde yapmış olduğu iltizamî muameleler keenlemyekûn olamaz. Bu misalde zikri geçen kadın, butlan kararından sonra ve fakat 18 yaşını ikmal etmeden tekrar evlenmek istese kanunî mümessilinin rızası lâzım gelir'. Keza sair iltizamî muamelelerde de izin veya icazet aranır.

Mutlak butlanla bâtıl olan evlenmede ikinci kadın evlenme akdi sırasında dâimî surette temyiz kudretinden mahrum olsa, evlenme ile rüşdden hiç istifade edemez. Zira, «evlenme kișiyi reșit kılar» kaidesi, mümeyyiz olanlar için câridir. Meselâ iki deli her nasılsa evlenmiş olsalar, evlenmekle hiç bir zaman reşit addedilemezler ve evliliğin devamı esnasında yaptıkları hukukî muameleler de muteber olmaz. Fakat reşit olmayıp da mümeyyiz olanlar, hattâ evlenme ehliyeti yaşını ikmal etmeden evlenmiş olsalar, mücerret evlenme akdinin ini-

(26) $125 / 2$ nisbî ve mutlak butlan hallerinde müşterektir.

(27) Şakir Berki, Medenî hukuk (Başlangıç, şahıs ve aile hukuku), Ankara, 1961, sa : 54 . 
kadı anından itibaren başka hiçbir muameleye lüzum kalmaksızın reșit olurlar (28).

126 incı maddenin 1 inci fikrası hükmü nisbî butlana, ve 120 inci maddedeki hüküm feshe dair olduğundan, mutlak butlana kıyas yolu ile tatbik edilmemek lâzımdır. Binnetice, evliliği mutlak butlan kararı ile zâil olan bir kadın, evlenme ile iktisap ettiği vaziyeti muhafaza edemez. Meselâ bir kız, babası veya bir erkek anası ile evlenmiș, yahut evlenme iki kardeș arasında akdedilmiş olsa, mutlak butlana karar verildiği andan itibaren kadın evlenmekle iktisap ettiği bütün hukuku zâyi eder (29). Zira, mutlak butlanla malul evlenme, ancak butlian kararına kadar sahih evliliğin hükümlerini tevlit eder.

\section{§. V - MUTLAK BUTLAN DAVASININ MİRASÇIYA İNTİKALI.}

127 inci madde, fesih davasına ait olmak uizere hüküm sevk etmiștir: «evlenmedeki fesih davası mirascılara intikal etmez. Ancak ikame edilmiş davâya mirascılar devam edebilir».

Bu hüküm evlenme akdinin nisbî butlan sebeplerinden biri ile taraflarca feshi haline aittir. Ana ve baba veya vasinin fesih hakkından bahseden 120 inci maddede derpiş edilmiş olan fesihle de alâkalı değildir. Ana babanın evlenmeyi fesh hakkı, șahıslarına münhasır bir haktır. Esasen vasinin açtığı fesih davâsının, vasinin ölümü ile mirascısına intikalini düşünmek de mümkün olmaz.

Şu halde yalnız nisbî butlan sebepleriyle feshe münhasır olan 127 inci madde hükmünü, mutlak butlana, klyasen ta bik mümkün olmaz. Ancak esasen mutlak butlan davasını alâkadarlar ve bu arada mirascı da bizzat açabileceğine gö-

(28) Bu neticeler, «evlenmenin kişiyi reşit kılacağı» kaidesinin normal, yani mutlak, nisbî butlan ve fesih sebepleriyle malûl olmayan evlenmelere münhasır kılınmamış olmasından doğmaktadır. Çünkü mutlak butlan ile bâtıl evlenmelerde, İsviçre ve Türk Medeni kanunlarının sarih hükümlerine göre butlan karamna kadar normal, sahih evlenmelerden farksızdır. 
re, taraflardan birinin ikame etmiş olduğu mutlak butlan da vâsının, davâcının veya davâlının ölümü halinde mirascıları tarafından devam ettirilebileceği tabiidir. Zira, Mutlak butlan davâsını, karı veya koca açmasa bile, alâkalı sıfatıyla mirascıların da açmaya selâhiyeti vardır. Fakat şunu kayd etmek icap eder ki, savcının açmış olduğu mutlak butlan davâsı sırasında karı veya koca vefat etse, davayı mirascılar tâkip edemez. Çünki bu halde mutlak butlan davası sakıt olur. Bu, zeval bulmuş olan evlenme hakkında re'sen butlan davası açllamıyacağını derpiş eyleyen 114 üncui maddenin 1 inci fikrasının ilk hükmü neticesidir. İște bu sebeple mirascıların davayı devâm ettirmeleri imkânsız hale gelir. Lâkin aynı fikranın ikinci hükmüne istinatla alâkadar mirascı, yani ölümle lehine miras açılmış olan mirasçı, isterse müstakillen dava ikame edebilir. Ölen tarafın mirascısının evlilik zeval bulduktan sonra dava ikamesinin mirasla alâkalı neticesi olamaz. Meselâ koca ölse, bunun çocuğu butlan davası açarak hayatda kalan eşin müktesep hale gelmiş olan miras pa yını izale edemez. Bu hususlar daha evvel izah edilmiști Hattâ bir erkek kız kardeşi ile evlense, ve ölse kız kardeși hayatta kalan eş olarak mirascısı olacaktır. Zira ölüm, butlan kararından evvel vâki olmuş ve binnetice kız kardeș, İsviçre ve Türk Medeni kanunlarına göre butlan hükmüne kadar aynı zamanda erkek kardeșinin sahih karısı hükmünde addedilmiștir. Bu kız kardeș erkek kardeșinin hem karısı, hem kardeşi sıfatiyle miraş̧ı olacaktır. Bütün bu neticeler İsviçre ve Türk medeni kanunlarının mutlak butlanla malûl olan her evliliği butlan kararına kadar sahih evlenmeye benzetmiş olan hükmünden doğmaktadır (30).

(29) Binnetice, kocanın vatandaşlık hakkı da tâkip olunamaz.

(30) Bu kanunların umumî sistemini bozan böyle neticelere sebep olmaması için mutlak butlan ile malul olan evlenmeleri keenlemyekûn addetmesi icabederdi. Mutlak butlan sebebi ile malûl evlenmelerden doğan çocuklarnn sahih nesepli çocuk statüsünden faydalanmalarını temin için çok şumullü bir kaide koyarak Poligami ve Poliandriyi bile meşra evlenme mertebesine yükseltmeye hiç lüzim yoktu. Çocuklarnn nesebinin sahih olacağını tasrih kifayet ederdi. 
Butlan kararından evvel vâki ölüm ile evliliğin zevali halinde miras açılır ve müktesep hak teşkil eder. O halde, ölümle zâil olan mutlak butlanla malûl bir evlenme hakkında mutlak butlan davası açmak, ancak şu neticeleri temin edebilir:

1) Kadın, kocasının soyadını taşıyamaz.

2) Kadın, kocanın vatandaşlı̆̆ını takip edemez.

3) Kadının dul maaşı alamaması.

İlk iki netice 125 inci maddenin 2 inci fıkrası hükmü ile de teyit olunur. Filhakika, bu fikra, ancak çocuklar ile ana baba arasındaki hak ve borçların boșanma hükümlerine tâbi olacağını kaydetmektedir. Binnetice boşanan karının ahvali şahsiyesi ile alâkalı bulunan 141 ve 142 inci maddelerdeki hükümler mutlak butlan kararında boşanma hükmünün neticelerine kıyasen tatbik olunamaz.

Ölümle zeval bulan mutlak butlanla malûl bir evlenme hakkında açılacak olan butlan dâvasının yukarıda kaydedilen $n^{e_{-}}$ ticelerden başka netice tevlit edeceği akla gelmiyor. Mamafih, bu hususda Medenî Kanunun boşanmanın mâli hükümlerinden bahseden 146 incı maddenin 2 inci fikrasındaki hükmünü de nazara almak làzımdır : Bu hüküm, gerek kanunî miras bakımından, gerek ölüme bağlı tasarrfular cihetinden mutlak butlanla malûl olup, ölüm ile zeval bulan evlilik hakkında bilâhara mutlak butlan kararı alınması halinde tatbik edilemez. Çünki mezkûr fıkra ancak evlilik boșanma ile zeval bulduktan sonra mirasın açılması halinde kabili tatbiktir. Evliliğin butlanına karar alınmadan evvel taraflardan birinin ölümü ile yalnız kanunî miras değil, ölüme bağlı bütün tasarrufların sebeb olduğu tevarüse ait menfaatler de hakkı müktesep haline geleceğinden, ölüm ile zeval bulduktan sonra hakkında mutlak butlan kararı alınan evlenmede hayatda kalan eș, vefat eden eşin kanunî mirasçısı olacağı gibi, muayyen mal vasiyetinden istifade etmek imkânını da bulur. Zira mezkûr fikra, ölüm, butlan kararından sonra vâki olmuş olsa idi, tatbik olunabilirdi. Mamafih, kaydedilmelidir ki, butlan kara ${ }^{\mathrm{r}}$ ndan evvel, evlenmenin ölümle zevali halinde, müteveffa vasiyetnamesinde vasiyet mevzuunun evlilik hakkında mutlak butlan kararına kadar hayatta kalan eșe aidiyetini tasrih etmiş ise, bu sarahate itibar etmek, ölüme bağlı tasrruflarda tasar- 
ruf sahibinin son arzu ve iradesine gösterilmesi icab eden sayg1 ve itina icabındandır. Bu halde, evlenme butlan kararindan evvel son bulmuş olsa bile, mutlak butlan kararından sonra vasiyet mevzuu hayatda kalan eș tarafından ya terekeye iade edilir veya müteveffa namzet göstermiş ise, fevkal'âde ikame esaslarına göre hareket olunur. Bu halde namzet, butlan kararının kesinleşmesinden evvel vasiyet mevzuuunu taleb edemez. Böyle bir talep, 471 inci maddenin sarahatine de aykırı düșer. Bu madde mucibince, nakil anına kadar namzedin va'siyet mevzuunda hiç bir hakkı yoktur. Maddenin 2 inci fıkrası, namzedin mirasa nakil ile malik olacağını açıkça kayd etmektedir. 